\title{
LA TRANSICIÓN A LA DEMOCRACIA... O LA CONSOLIDACIÓN DEL CHILE QUE PINOCHET SOÑÓ
}

\author{
Alejandra Farías Köbnenkampf
}




\section{ALEJANDRA FARÍAS KÖHNENKAMPF}

Licenciada en Humanidades con mención en Lengua y Literatura Hispánica de la Facultad de Filosofía y Humanidades de la Universidad de Chile y Máster en Gerontología Social de la Universidad Autónoma de Madrid. Es coordinadora académica y docente en el postítulo para profesores en ejercicio del sector de Lenguaje y Comunicación en el Centro de Estudios y Desarrollo de Educación Continua para el Magisterio -Saberes Docentes- de la Facultad de Filosofía y Humanidades de la Universidad de Chile. Desde el año 2000 se ha dedicado a la educación, perfeccionando a profesoras y profesores en temáticas y metodologías orientadas a la comunicación, la creatividad y el desarrollo de recepción crítica de medios masivos - alfabetización mediática. 


\section{LA TRANSICIÓN A LA DEMOCRACIA... \\ O LA CONSOLIDACIÓN DEL CHILE QUE PINOCHET SOÑÓ}

"Cuando dicen 'le ganamos a Pinochet'... pienso que no es verdad. No le ganamos", afirmaba Ana González, una de las fundadoras de la Agrupación de Familiares de Detenidos Desaparecidos, en una de sus últimas entrevistas antes de morir sin haber encontrado a ninguno de sus cuatro familiares detenidos y desaparecidos ( $E l$ País, 11 de septiembre de 2018). Si bien la afirmación suena aterradora para muchos de los y las que luchamos por el fin de ese periodo aciago, la realidad cotidiana le da la razón de múltiples formas.

Este texto indagará en los procesos de consolidación y legitimación del imaginario del Chile que Pinochet soñó, entendido como el conjunto de re-presentaciones que dan significado, que sustentan un modo de concebir el país y a sus habitantes. Con este fin se focalizará la atención específicamente en la producción discursiva gestionada por los medios de comunicación de masas y se ejemplificará básicamente con la televisión abierta y los anuncios callejeros.

Así, se propone observar e interpretar desde un enfoque comunicacional que mira el tránsito de estos mensajes masivos, sus emisores y las consecuencias de su recepción, para desde ese lugar/contexto argumentar que lo que hoy se llama proceso de transición a la democracia, a nivel de las representaciones que construyen el imaginario, no es más que una estrategia discursiva que se estructuró en base a una serie de maniobras. La primera de ellas, recuperar el discurso hegemónico que se había perdido en los últimos años de la dictadura gracias a la aparición de un nutrido "discurso opositor". La segunda maniobra se consolida con la expansión e hibridación del discurso publicitario a otros ámbitos de enunciación, y la última, los procesos de formación o deformación de las audiencias para su recepción y adherencia.

En una segunda parte se describirán esas re-presentaciones estructurales del imaginario postdictadura que consiguen el afianzamiento del Chile que el dictador imaginó, como afirmó lúcidamente Anita. La atención se centrará en las imágenes/ conceptos a las que estamos expuestos, lo que inunda nuestro campo de visión, para pasar, por último, a lo que estas imágenes/conceptos ocultan, las ausencias que esas presencias involucran. 


\section{LA PRIMERA MANIOBRA: LA RECUPERACIÓN DEL DISCURSO HEGEMÓNICO}

Para iniciar esta reflexión que se orienta a identificar las transformaciones discursivas (básicamente en el campo audiovisual) que disimulan la consolidación del Chile de Pinochet es necesario volver a la fuente. En esta idea se presenta a continuación una breve cita, que resume muy bien el sustento teórico del sueño pinochetista (inspirado en el pensamiento de Milton Friedman) y creada por su más brillante gestor intelectual, Jaime Guzmán:

“... se revitalizan así la propiedad privada y la iniciativa particular ${ }^{1}$, como bases para un crecimiento alto y sostenido de la economía. Un estado subsidiario disminuye su tamaño y orienta su función a superar la pobreza -y no a una utópica igualdad-como instrumento de efectiva justicia social. Se restituye a cada persona la libertad real para decidir su destino, liberalizando o privatizando -según el caso- el mayor margen posible de ámbitos como la educación, el mercado laboral, el sindicalismo, la seguridad social, la salud y la tarea empresarial. En fin, se comprende que la libertad política requiere afianzarse sobre la vigencia de la libertad económica, social, a la vez que sobre una postura energética y eficaz frente al comunismo" (Citado en Retamal, 2013, p.38).

Con el triunfo del No y la eufemísticamente llamada transición a la democracia se inicia una nueva etapa indiscutible en la historia del país. La controversia no surge por un cuestionamiento a la recuperación de un sistema presidencial y parlamentario, lo que es innegable, sino por la mantención, legitimación y consolidación de un conjunto de representaciones que establecen valores y concepciones de mundo que el régimen militar impuso.

Con la asunción de Patricio Aylwin como Presidente de la República en 1990 se inician los gobiernos de la Concertación, primero, y los del bloque de derecha y ultraderecha de Sebastián Piñera, luego. En todo este periodo, con mucha dificultad al inicio y en la medida de lo posible ${ }^{2}$, se realiza un proceso de diferenciación y distinción

1. De aquí en adelante, las negritas en las citas textuales son de la autora.

2. Frase de Patricio Aylwin en su discurso del 21 de mayo de 1990 en la inauguración de la legislatura ordinaria en el Congreso Nacional después de 17 años de dictadura militar. Enunciado que alude al ejercicio de la justicia y al esclarecimiento de la verdad sobre las violaciones a los derechos humanos entre el 11 de septiembre de 1973 y el 11 de marzo de 1990, dentro y fuera del país. El párrafo desde donde se desprende esta oración dice: "La conciencia de la nación exige que se esclarezca la verdad, se haga justicia en la medida de lo posible -conciliando la virtud de la justicia con la virtud de la prudencia- y después venga la hora del perdón”. 
intencionada con la etapa previa. Al parecer, urgía borrar "los excesos", las huellas, retirar los televisores ${ }^{3}$ para retocar "la pifia" dictatorial con el Chile multicolor que llegaba con la Concertación.

La indiscutible mayoría que hizo posible el triunfo del No y luego la elección del primer presidente democráticamente elegido después del quiebre institucional exigía empoderada justicia y fin al atropello de los derechos humanos que la dictadura había generado de forma "energética y eficaz frente al comunismo", parafraseando a Guzmán. Pero la jugada de ajedrez había sido inteligente y creativamente preparada en los años de régimen militar para que la transformación fuera aparente, y si bien algunas prácticas de coerción social se detuvieron (desapariciones, relegaciones y exilio), las referidas a la utilización de ciertas representaciones y su impacto en el imaginario se consolidaron a partir de originales estrategias, las que se focalizaron en una producción discursiva que utilizó los medios masivos como su más eficiente dispositivo de generación de sentido, opinión y nuevas identidades. Había que transformar a los humanoides y subversivas en compulsivos consumidores.

Los gérmenes de esta estrategia discursiva se pueden identificar ya en la campaña del Sí que la ultraderecha elaboró para su fallido triunfo (en las urnas), pero que sin duda le obsequiaron los aprendizajes necesarios para el diseño de esta otra ofensiva que lenta, repetitiva y magistralmente les permitió a los sectores conservadores y dueños del capital el éxito que hoy, sin duda, ostentan.

Desde la crítica y los estudios culturales esta estrategia ha sido ampliamente reconocida y denunciada, son múltiples los textos y los autores y autoras que teorizan sobre ello. Nelly Richard, Diamela Eltit, Manuel Antonio Garretón, Raquel Olea, Tomás Moulian, Margarita Pisano, Carlos Ruiz, Luis Cárcamo-Huechante, Olga Grau y tantos otros y otras. Fragmentos como: "En el modelo económico implementado por la dictadura militar de Augusto Pinochet, diametralmente opuesto al modelo socialista de Salvador Allende, también se impuso en la mentalidad de los chilenos, ya que se promovieron valores como el individualismo, la competencia y el consumismo" (Medina-Sancho, 26) van en esta línea, o "El libre mercado se constituye en un discurso cultural que, a partir de un conjunto de intervenciones retóricas e imaginarias, se despliega hegemónicamente en la sociedad: un escenario de intensificada y espectacularizada circulación” (Cárcamo-Huechante, 17).

Sin embargo, llama la atención cómo estas lecturas e interpretaciones de la realidad y la historia del país se mantienen clausuradas en el ámbito de la academia,

3. Nombre en clave que el Ejército chileno dio a la operación de desentierro y eliminación de los restos de las y los detenidos desaparecidos a fines de 1975, hasta ese momento en fosas clandestinas. Así se hizo desaparecer evidencia fundamental para poder conocer la forma y la dinámica estatal de esos crímenes. 
la crítica y literatura especializada, y no logran permear el discurso de los medios masivos. De esta forma, permanecen "prohibidas" o "censuradas" para la y el ciudadano común y especialmente para las nuevas generaciones. La identificación de esta táctica (aludiendo al lenguaje militar desde donde seguramente surge) nos permite avanzar en el develamiento de estas operaciones de ocultamiento y censura.

Si bien la dictadura militar chilena y los poderes fácticos que la sustentaron por casi dos décadas utilizaron de forma sistemática el control y la censura de la información, una vez concluida (en lo formal) se mantienen estas restricciones, pero con una estrategia distinta y perfeccionada por la experiencia.

\section{LA PÉRDIDA DEL DISCURSO HEGEMÓNICO DE LA DICTADURA}

Desde el primer día del derrocamiento del gobierno de la Unidad Popular se tuvo especial cuidado en revisar y controlar los mensajes emitidos por la prensa, la radio y la televisión del país. Este manejo, que luego avanzó hacia un modelo bastante reconocible de manipulación y tergiversación de datos, noticias y acontecimientos, hizo posible una década después, paradojalmente, una cada vez más importante aparición de proyectos y medios "alternativos" de comunicación. Entre ellos, los periódicos Fortín Mapocho y La Época, y revistas como APSI, Cauce, Hoy, Análisis, El Canelo, Crítica Cultural, La Bicicleta, y las radios Cooperativa, Chilena, Umbral, Tierra, entre otras'.

Pero detengámonos en la etapa de la manipulación y tergiversación de información que fue sistemáticamente desplegada por los medios masivos de la dictadura. Me interesa principalmente uno: el montaje. Término que en esos días pasó a definir la noticia que previamente era "preparada". Es decir, una vez construida la "idea fuerza" se procedía a buscar la escenografía, los personajes y la ambientación, para luego cámara y micrófono en mano "darle vida" y "registrarla" para ser difundida incansablemente en los noticieros de la mañana a la noche. Así aparecen los síntomas de una realidad simulada, que claramente en sus albores rayaba en la chabacanería. Unas décadas después las ideas fuerza siguen siendo las mismas, pero ahora hay conocimiento, tecnología y mucha experiencia. Ya volveremos sobre esto.

Gracias a la explosión de estos nuevos medios de comunicación masiva surge un nutrido "discurso de oposición" al régimen dictatorial, que opera como un nuevo polo de generación de sentidos y, por lo tanto, de nuevas re-presentaciones que construyen otras formas de ser y estar en el mundo.

4. También se desarrolló una interesante producción audiovisual con Teleanálisis, que operaba como un "noticiero envasado", aportando un valioso registro de la época. Una multiplicidad de radios comunitarias contribuyó significativamente y se establecieron, como estos, otros emisores. 
Sin embargo, este discurso opositor se había iniciado mucho antes, como un balbuceo deformado por el miedo pocos meses después de la llegada de los militares y desde "la informalidad", ya que ante el férreo control de los periódicos, radios y canales de TV la subversión hizo uso de panfletos, rayados en las murallas y publicaciones a mimeógrafo. Son numerosos los periódicos e informativos clandestinos y por lo mismo, de circulación restringida, que iniciaron esta producción discursiva en oposición a la palabra dictatorial.

Estos medios, tanto formales como informales, dieron nacimiento a un tipo de enunciados que no solo reaccionaban y desmontaban sistemática y significativamente las "verdades del régimen", sino que gestionaban un foco de sentidos e interpretaciones de lo real que permitían fundar "otro Chile" basado en el cuestionamiento de su modelo económico (que aquí también estamos entendiendo como un sistema cultural) y que fue instaurado por la fuerza y con extremada violencia. Estos emisores, en su gran mayoría hombres, propugnaban con sus enunciados y re-presentaciones otro país muy distinto al del dictador, en el que la libertad de expresión, el respeto a los derechos humanos, la justicia y la verdad estaban a la base de su propuesta.

Esta interesante y cuantiosa producción operó no solo como una estrategia de oposición al discurso hegemónico de la dictadura sino que además hizo posible la aparición de un amplio abanico de voces empeñadas en establecer otras "ideas fuerza", otras formas de estar en el mundo que amenazaban con fragmentar el principio sagrado del mercado y su idolatría de la propiedad privada.

Todo este proceso de producción discursiva bosquejó un mythos ${ }^{5}$, un Chile libre, justo y solidario, y un logos, como relato, que no alcanza a ser puesto en acción y a manifestarse en la praxis social. Esta producción, si bien se proclamó inclusiva y democrática, mostró, salvo honrosas excepciones, fuertes resistencias frente a la incorporación de al menos tres temas/causas tan legítimas como urgentes: violencia hacia las mujeres (en tanto género), hacia la diversidad sexual y hacia los pueblos originarios. Pese a que sus dirigentes y voceras logran participar eventualmente en esta producción discursiva, sus apariciones son inusuales y acotadas, dando cuenta de su precaria instalación pese a su importante participación en la resistencia antidictatorial. Operó la idea de que esas luchas eran para un segundo momento, el cual llegó solo cuando estos actores se tomaron las calles y la palabra, lo que no significó necesariamente una victoria definitiva, pero sí un impacto en los discursos y

5. Concepto usado desde el enfoque sociocomunitario, que Víctor Martínez define como el relato donde se construye y sostiene lo común de la comunidad. 
el lenguaje. Esta resistencia nos permite identificar zonas de tensión que retomaré en la parte final de este texto.

Con esta lógica es posible establecer que si bien la dictadura desarrolló consciente e intencionadamente un discurso hegemónico, la creatividad de sus subyugados/ as, el poder de la autogestión, el financiamiento de la cooperación al desarrollo y el apoyo político y monetario a través de la adquisición sistemática y consecuente dieron origen a un discurso alternativo capaz de cuestionar y leer críticamente el relato único del régimen. Tanto así, que generó las bases y fundó las estrategias para su caída, a través, claro, de estimular una intensa movilización social que obligó, ya en su última etapa, a un plebiscito que puso fin a las pretensiones de Pinochet de seguir en el poder.

\section{EL RENACIMIENTO “TRANSICIONAL” DEL DISCURSO HEGEMÓNICO}

Pero la "alegría no llego 6 ", más bien se nos "murió el sol de primavera en la ventana" y casi sin que nos diéramos cuenta, entre tanta foto, entrevista celebratoria, campaña electoral y festejo autocomplaciente, fueron muriendo uno a uno los medios "de oposición", y junto con la banda presidencial en manos de la Concertación llegó un nuevo discurso hegemónico, esta vez sin oposición y cuestionamiento, y que espero describir a partir de las re-presentaciones o imágenes que le dan vida.

Pudimos aprender, entonces, que los Chicago Boys y sus discípulos nos daban una nueva y contundente lección. Las dinámicas del mercado ${ }^{8}$ eran mucho más eficaces que los bandos militares, el bombardeo de antenas, las quemas de libros, el asesinato de periodistas, la destrucción de archivos, la amenaza, la tortura y el hostigamiento. Las estrategias perfectas fueron el financiamiento (o desfinanciamiento) y la cooptación de la mayoría de las y los emisores críticos de antaño, en ese orden.

Respecto al financiamiento de proyectos comunicacionales, varios estudios han llamado la atención sobre el impacto que tienen las elecciones y decisiones de los avisadores, entendidos como los generadores de avisos publicitarios, ya que controlan, administran y definen los espacios, medios y plataformas en que se compran los espacios publicitarios, contribuyendo y asegurando así su operación y sobrevivencia.

6. Transformación de la consigna "la alegría ya viene" que dio origen al himno de la franja del No, cuya música y letra fue creada por Jaime de Aguirre y Sergio Bravo.

7. Fragmento de la canción de la época "A mi ciudad", del grupo Santiago del Nuevo Extremo.

8. "Las fuerzas del libre mercado son más eficientes que la intervención pública", propone el mismo Milton Friedman desde su teoría monetarista. 
“... los antecedentes relacionados con el mercado de la publicidad resultan especialmente interesantes puesto que ni en el caso de la televisión ni en el de la prensa escrita se observa, como cabría esperar, una correlación estricta entre los niveles de audiencia de los medios y la inversión publicitaria. Este desequilibrio no debe ser considerado una situación meramente anecdótica, puesto que influye directamente en la sustentabilidad económica de los distintos medios de comunicación, al constituir la publicidad su principal fuente de ingreso (Corrales y Sandoval, 18).

Presenciamos la sagacidad del mercado para aniquilar, aludiendo a las reglas de su propia naturaleza, las voces disidentes y las lecturas indeseadas, y, sobre todo, las alertas tempranas sobre el nuevo "silencio" que se nos venía irremediablemente encima. La falta de financiamiento, ya fuera por la desaparición de comprometidos lectores y/o auditores, la retirada de los fondos de la cooperación internacional, el deslumbramiento con los nuevos medios de comunicación ${ }^{9}$ - Internet y las redes sociales- y el omnímodo poder de los avisadores aniquilaron esas plataformas analógicas que habían logrado a costa de mucho esfuerzo construir una voz alternativa y disidente al discurso del dictador. Uno a uno fueron cayendo los proyectos comunicacionales, no por falta de ideas o propuestas, sino por la falta de los recursos económicos mínimos para su funcionamiento. Junto con el retorno de las urnas y el voto asoló la sospechosa política del autofinanciamiento, que obligó a estos medios a buscar nuevas formas de obtención de recursos en el intento de sobrevivir con proyectos anti neoliberales en el territorio propio del mercado. Otra importante derrota, habría sentenciado Anita González.

Así, asistimos a la creciente y sostenida concentración de medios masivos. Una vez más, los poderosos grupos económicos del país tomaron el control de la situación (o nunca lo perdieron, solo simularon hacerlo) y trazaron la arquitectura de un nuevo "diseño cultural", enarbolando las banderas del individualismo, la competencia y el consumo tras el engañoso velo de la libertad para "decidir el propio destino", como prescribiera Guzmán en la cita inicial.

Esta nueva habilidad que "la naturaleza del mercado" develaba, dejar morir de inanición a su enemigo, habiéndole previamente desangrado a través de una competencia desleal (con sus estocadas de marketing y de fidelización del cliente a su favor), dio origen a la más grande concentración de medios de comunicación

9. Sobre los medios digitales de comunicación o mass media me referiré en la última parte del ensayo, ya que ellos establecen nuevos espacios discursivos, situación que también proyecta una luz de esperanza. 
de la historia del país, a excepción, claro, de los primeros años luego del 11 de septiembre de 1973.

Varios investigadores e investigadoras pusieron sus mejores esfuerzos, sorteando amenazas y hostigamiento, para prevenir sobre esta peligrosa aglutinación y las desastrosas consecuencias para la libertad de expresión, entre ellos María Luisa Mönckeberg, Patricia Verdugo, Osvaldo Corrales y Juan Sandoval.

En el 2015 las alarmas continuaban denunciando, esta vez desde los hallazgos realizados a partir del estudio encargado por el Consejo Nacional de Televisión (CNTV) al experto Luis Adolfo Breull, que detallaban que "los cuatro principales operadores en cada sector de medios de Chile (o índice CRA $4^{10}$ ) concentran más del 90\% del mercado, cuando en América Latina el promedio es 80\%. En la TV abierta y de pago, el índice de concentración también llega al 91\% y al 87\% (en audiencia e ingresos publicitarios, respectivamente)" (CNTV).

Esta faceta fagocitadora de la "naturaleza del mercado" que da origen a esta masiva concentración de medios de comunicación asegura, nuevamente, pero con estrategias distintas, la hegemonía en el discurso mediático y cultural.

Frente a esta constatación podemos preguntarnos: ¿qué pasó con la tan ansiada libertad de expresión que exigimos hasta enronquecer en las marchas y los mítines previos a la llegada de la transición?

La censura, ya lo dijimos, como muchas de las estrategias de coerción de la dictadura, no desapareció, solamente mudó sus ropajes y se maquilló con los colores del arcoíris para disimular su transformación. Ahora no amordazaba a los emisores de verdades incómodas sino que propiciaba un inteligente desplazamiento desde el silenciamiento del emisor al exterminio del medio, soporte/plataforma de su enunciación.

El resultado: la aparición de poderosos conglomerados, que se fue dando de manera natural gracias a las condiciones y habilidades que el mismo mercado posee y por las cuales ha logrado que muy pocos emisores (y aquí uso el género intencionadamente) se tomen la palabra y la perfilen sin legislación alguna que nos proteja de esta práctica monopólica. Hay que recordar que el monopolio atenta contra las propias reglas del libre mercado, no obstante, no hay reacciones eficaces de organismo estatal alguno que observe, denuncie y desarticule esta nociva práctica.

10. Concentration Ratio (CR): mide la concentración en propiedad, ingresos y/o audiencia. Se calcula respecto de la primera empresa con mayor concentración y luego las cuatro empresas más concentradas. 
Esto hace posible que hoy nos enfrentemos a un discurso mediático, desde la TV, por ejemplo, con asombrosas similitudes en sus líneas editoriales ${ }^{11}$.

Sin embargo, sería muy ingenuo pensar que la compleja estructuración de las representaciones que conforman el imaginario sobre el que vamos a trabajar luego se elabora solo en base a esta estrategia. Es cierto que la recuperación de un discurso hegemónico es clave para este propósito, pero aún hay más relaciones y mediaciones que visibilizar. Una que responde al código, forma y estructuración de los mensajes, y otra que define y articula las competencias para su decodificación, comprensión y adherencia por parte de las audiencias a las que están destinados.

\section{LA SEGUNDA MANIOBRA: LA EXPANSIÓN E HIBRIDACIÓN DEL DISCURSO PUBLICITARIO A OTROS ÁMBITOS DE ENUNCIACIÓN}

La campaña mediática del Sí detonó los aprendizajes (especialmente respecto a lo ineficaz de basarse en estructuras dicotómicas y en el miedo explícito al pasado para hablar del futuro), pero para nuestra sorpresa, la campaña del No aportó más todavía al tipo y organización del nuevo, hegemónico y seductor discurso del mercado. La campaña del No co-inaugura los mega discursos que a partir de su factura audiovisual construyen un ideal de sociedad que opera como dispositivo articulador de sentidos, los que no necesariamente llegan a transformarse en realidad, pero que sin embargo, consiguen instalar y consolidar una serie de imágenes y representaciones tan potentes que quedan impresas significativamente en la memoria como hito mediático fundamental en la lucha contra la dictadura. El producto audiovisual construido, que moviliza magistralmente todos los elementos del lenguaje audiovisual, se pone al servicio de un conjunto de símbolos que sostienen la idea de "una nueva etapa" y consiguen re-presentar ese deseo sin que llegue necesariamente a concretarse. Esta construcción en la que participó activamente lo más granado del mundo intelectual, audiovisual, artístico y creativo opositor al régimen, puso en movimiento las artes que había aprendido en el terreno más próximo y esencial del mercado: la publicidad.

Así, los dueños del capital, mirando de reojo, aprendieron a crear con palabras, generalmente vaciadas de sentido, enunciados y principalmente imágenes capaces

11. Es interesante observar cómo hoy los noticieros de la televisión abierta presentan el mismo listado de noticias, incluso con las mismas imágenes y los mismos entrevistados. La entrega de información se inicia habitualmente en todos los canales con hechos delictuales, los que muchas veces componen más de un tercio del noticiero completo, generando una sensación de inseguridad y peligro, lo que se contradice con las cifras, a nivel latinoamericano, que el país ostenta en estas materias. 
no solo de "construir realidad" sino de modelar las necesidades, los sueños y las aspiraciones de las y los ciudadanos de antes y principalmente consumidores de hoy.

De este modo, el discurso publicitario comenzó a levantarse como el gran estructurador de la enunciación mediática y permeó con sus características y códigos la mayor parte de los mensajes que los medios masivos producen, obviamente en los espacios establecidos para ello, pero extrapolado vertiginosamente a un sinnúmero de producciones discursivas, entre ellas las de la política, la información noticiosa y hasta del habla. Esto se hace evidente, por ejemplo, cuando en el noticiario nocturno se dan a conocer los restaurantes gourmet de una determinada comuna. ¿Esto opera como noticia o publicidad?

La publicidad, como disciplina, como escenario cultural, pero principalmente como género mediático, ha sido capaz en muy breve tiempo de nuclear en su producción la amplia gama de recursos no solo lingǘsticos sino también visuales, auditivos, semánticos, expresivos y multimodales que le permiten sustentar su poderosa influencia. El sonido, la imagen, el movimiento, la tipografía, la animación, etc. se han transformado en los ingredientes que construyen los mensajes más presentes y menos regulados de la realidad nacional.

“... la publicidad, como institución que forma parte de la cultura de masas, gira en relación al consumo, su finalidad es promoverlo, generar la ilusión de la satisfacción. Por lo tanto es más que un conjunto de técnicas elaboradas y utilizadas racionalmente, para impactar sobre los potenciales consumidores; puede ser considerada un signo en el sentido de Pierce; ya que dice algo que no está totalmente contenido en las frases e imágenes en que se presenta. Vale decir que es un espacio discursivo que opera simbólicamente, que remite a múltiples significaciones que circulan en el espacio social. Transmite algo más que la necesidad o el deseo de adquisición de un objeto. Nos reenvía imágenes que exceden su valor de uso. La publicidad refuerza con su lenguaje el carácter de fetiche que Marx atribuyó a los productos del trabajo de la sociedad capitalista. Opera en un horizonte más amplio que el del circuito comercial. Es formadora y reproductora de imágenes sociales" (Morresi, 162).

El conocimiento que se despliega en cada comercial da cuenta de una gestión sólida y profesional que ha recurrido a un sinnúmero de disciplinas para comprender, primero, y utilizar, después, las formas en que el cerebro percibe información y opera, incluso para dar inicio a nuevas "ciencias" como el neuromarketing, la neuromercadotecnia y el marketing relacional. Así, los gestores publicitarios, dirigidos y financiados por los grupos económicos, han sabido ensamblar cada uno de estos conocimientos para crear un mega-mensaje capaz de movilizar al consumo, pero 
también de estructurar el imaginario y los referentes simbólicos para las audiencias que seducen en cada intervención en radio, TV abierta o pagada, cine, prensa y ahora en la web ${ }^{12}$. Su presencia está tan normalizada que para los niños pequeños los anuncios forman parte de los dibujos animados que ven.

Los formatos y recursos comunicacionales híbridos ${ }^{13}$ de la publicidad se mostraron tan efectivos que lentamente han ido construyendo, junto al discurso de los economistas, un nuevo vocabulario, que desde el uso y abuso da forma y estructura al imaginario del que Pinochet seguramente estaría muy orgulloso. El dictador no solo murió en su cama sin ser juzgado por sus horrendos crímenes y estafas sino que sus adeptos y un número indeterminado de cómplices pasivos ${ }^{14}$ han hecho posible la concreción de su sueño: el paraíso intencionadamente mal regulado de la economía social de mercado.

De este modo, es posible identificar relaciones y vasos comunicantes que no solo van consolidando la hibridación que este discurso va gestando con su "expansión" sino que se van develando las dependencias entre la concentración de medios masivos que lo sostienen y los ámbitos que lo regulan, o al menos debieran estar a cargo de su regulación, el Parlamento de la República, por ejemplo.

"El problema es que los políticos tienen una doble dimensión: por un lado, pueden estar de acuerdo con mayor libertad de expresión y menos concentración, pero saben que su carrera está determinada por los mismos medios y en última instancia tratan de no confrontarse con estos conglomerados. Por lo mismo, sus declaraciones suelen ser más bien 'timoratas' respecto de lo que finalmente terminan haciendo", comentó el investigador y docente argentino Guillermo Mastrini (Figueroa, 1).

12. Es común escuchar la fantasiosa idea de la web y especialmente las redes sociales como espacios democráticos, participativos y libres de la influencia de la publicidad, nada más falso, ya que cada día los avisadores se las ingenian para influir con sus anuncios, travistiéndose con los recursos propios de estos espacios de comunicación. Y si así fuera, no hay que olvidar que el proceso de inducción a la publicidad ya ha sido realizado (casi con la leche materna) y se pone en operación ante los más leves estímulos (puede ser publicidad sin siquiera parecerlo).

13. La hibridación en los medios masivos de comunicación es un fenómeno que se ha intensificado en los últimos años y que consiste en la convivencia de rasgos referenciales y ficcionales. "Los géneros mediáticos se contaminan, comparten convenciones, se citan unos a otros, lo que lleva a la co-existencia de características diversas", afirma Gabriela Fabbro. Tengo la impresión de que fue la publicidad la que primero y con más fuerza puso en acción este fenómeno.

14. Caracterización que usó Sebastián Piñera para referirse, en el marco de la conmemoración del golpe militar, a quienes "no sabían y no hicieron nada o no quisieron saber y tampoco hicieron nada" frente a los atropellos a los derechos humanos y la dignidad de las personas durante la dictadura militar. 
Ahora avancemos sobre una caracterización del discurso publicitario, el que activa la "utilización de un conjunto de técnicas persuasivas a través de diferentes medios de comunicación, cuyo objetivo final es favorecer la venta de determinada mercadería" (Sánchez-Guzmán, 16) y que configura, a partir de la reiteración en distintos formatos, periodos de exposición, medios de comunicación y contextos, un metarrelato que fija conductas, identidades y visiones de mundo. Es una producción cultural de reciente masificación en Chile (a partir del siglo XX) que moviliza y se sustenta en diversos lenguajes, en los que la palabra, pero principalmente la imagen se constituye en su significante de mayor impacto.

Con indiscutible predominancia de la función apelativa del lenguaje, el discurso publicitario activa también sus funciones referencial y expresiva, lo que le permite hibridar los géneros discursivos argumentativo, expresivo y expositivo/descriptivo. En suma, reúne sobre sí las funciones del lenguaje y los géneros discursivos más frecuentes y fundamentales de la comunicación humana.

“... como práctica cultural [la publicidad] excede el carácter mercantil e industrial. Constituye al mismo tiempo un sistema de comunicaciones que en su mismo funcionamiento (para incidir en el mercado que es su finalidad), utiliza mecanismos que producen y reproducen gustos, deseos, formas de comportamiento, etc." (Morresi 161).

\section{LA TERCERA MANIOBRA: LA EDUCACIÓN DE MERCADO}

En la idea de realizar una síntesis que permita comprender los pasos y ámbitos descritos hasta el momento y relacionados con una de las estrategias que ha hecho posible el triunfo del Chile que el dictador soñó, podemos afirmar que parte de la operación ${ }^{15}$ consistió en: (a) restituir la hegemonía del discurso a través de la concentración de medios masivos; y (b) exportar los códigos y los recursos del discurso publicitario a un amplio espectro de ámbitos de enunciación.

Propongo otro elemento que completa el cuadro y que se refiere a la definición y desarrollo de habilidades y competencias necesarias para que las grandes audiencias realicen una "adecuada" y planificada recepción/adherencia de estos discursos.

15. En este texto se intenta describir y problematizar solo una parte, una pequeña parte (lo referido al discurso hegemónico y su impacto en el imaginario y los referentes simbólicos) de las estrategias que han hecho posible la consolidación del Chile de Pinochet. 
Para lograrlo, fue Jaime Guzmán nuevamente quien aportó la pieza faltante: estructurar un sistema educativo afín y funcional a los dos pasos previos. Complementa este pack la educación de mercado.

La educación de mercado creada y puesta en práctica por el gobierno dictatorial y "perfeccionada" por los gobiernos siguientes se estructuró a partir de los siguientes elementos: (I) la subsidiariedad del Estado, lo que en la práctica significa su reducción a la mínima expresión. "Esta inhibición del Estado no afecta sólo a su propia acción directa en la economía o a sus dimensiones normativas y protectoras, sino que opera también neutralizando todas aquellas interferencias del mercado que puedan provenir de intereses corporativos o derechos sociales y laborales" (Águila, 1); (II) la descentralización de la educación pública a través del traspaso de la administración de los establecimientos de propiedad del Estado a los municipios y a entidades educacionales privadas, reconocidas como cooperadoras de la función educacional del Estado; y (III) la instauración de la subvención por alumno asistente a cada escuela. El nuevo financiamiento deja "de costear la oferta del servicio educativo y en su reemplazo entrega a las escuelas un aporte -la subvención escolarpor cada alumno efectivamente asistente a la escuela; se acaba la diferencia entre el financiamiento de las escuelas públicas, que ahora serán administradas por los municipios, y el financiamiento de las escuelas creadas por privados [...]. En esta nueva modalidad, las escuelas deberán competir por la matrícula para financiarse" (Corvalán y García-Huidobro, 2). Si bien actualmente se está en proceso de cambio y eliminación de algunas de estas medidas, estamos muy lejos de ver esos resultados.

Todas estas iniciativas, que surgieron de un marco valórico que a su vez estableció concepciones/símbolo, no hicieron más que acrecentar las desigualdades "tradicionales" de este país, lo que además hemos constatado de diversas formas todos estos años ${ }^{16}$. Pero la desigualdad, que se refleja finalmente en oportunidades de acceso, en este caso de desarrollo de competencias y conocimientos, responde a una concepción filosófico-religiosa que convierte a unos en "guías" y a otros en "rebaño". El propio Jaime Guzmán aseguraba que el mismo creador nos hizo desiguales. En sus palabras: “...siempre el progreso se ha logrado por el fruto con que la obra de pocas eminencias cumbres se ha derramado sobre el resto del cuerpo social. Y el logro del bienestar material no constituye una excepción a dicha realidad. Lo único difícil es que ello implica aceptar la desigualdad como un dato de la Creación. Por ello es que la utopía del igualitarismo absoluto paga siempre el precio de lo antinatural" (Citado en Retamal, 2013, p.39).

16. Lo que ha dado origen a importantes movimientos sociales en defensa de la educación, demandando una educación pública de calidad, gratuita y no sexista. 
La brutal divergencia que durante años fue creciendo entre comunas ricas y comunas pobres respecto de la adquisición (o no) de aprendizajes en sus estudiantes motivó múltiples estudios, un número importante de críticas y desmentidos varios, pero principalmente dejó en evidencia, y especialmente a través del propio mercado, que se generó una educación para la formación de la mano de obra barata y otra reducida y exclusiva para quienes conformarían los espacios de poder y conducción. Estas diferencias, que esencialmente se reflejaron en la calidad de la educación para unos/as y otros/as, hizo posible que los procesos formativos para una gran mayoría de estudiantes no les entregaran las herramientas básicas para el ejercicio de una adecuada comprensión (de enunciados visuales, orales o escritos) y menos lecturas críticas de los mismos. Es decir, los procesos de alfabetización, en sus distintos niveles de complejidad, perdieron relevancia frente al cumplimiento de metas estimuladas por "la competencia del mercado" (SIMCE, especialmente). Así se abonó y preparó el terreno para que el nuevo discurso hegemónico fuera fácilmente "digerido" y recibiera la adherencia planificada en el público masivo.

Eso respecto a la forma. Sobre el fondo, la construcción de nuevos marcos curriculares que acompañó a estos cambios en el financiamiento utilizó el modelo por competencias, que se focalizó principalmente en el desarrollo de habilidades, contenidos y actitudes orientadas a los "procesos productivos", es decir, al mundo del trabajo y la empleabilidad, con una clara y sostenida disminución y acorralamiento de las expresiones artísticas (se fusionó Artes Visuales con Artes Musicales y las cuatro horas semanales que antes se consideraban para ambas manifestaciones artísticas quedaron reducidas a dos) y la Filosofía (se eliminó definitivamente del currículum de la educación técnica-profesional), áreas del conocimiento reconocidas por estimular la reflexión y la recepción crítica y, a través de ella, generar identidad, lo que puede ser beneficioso para quienes toman las decisiones, pero de gran incomodidad en quienes deben obedecerlas.

\section{LA IMAGEN COMO REPRESENTACIÓN Y CONFIGURACIÓN DEL IMAGINARIO}

Después del triunfo del No había que reorientar las estrategias de modo de convertir ese triunfo, lo que a la luz de esta mirada es más bien una derrota, en el triunfo del modelo que había impuesto la dictadura, pero borrando su huella y presencia. Así, el mal llamado proceso de transición a la democracia no fue más que la consolidación de la economía social de mercado como sistema económico y, más relevante para este análisis, como imaginario y sistema simbólico y cultural.

Pero analicemos ahora las consecuencias o, mejor dicho, el resultado del proceso que recupera la hegemonía discursiva, la impregna con discursos específicos, el 
publicitario en la estrategia y el económico en el fondo, y paralelamente forma (o deforma) las audiencias que completarán y así movilizarán la impronta "social" de mercado; consumo, competencia e individualismo.

Sin duda, la empresa no era sencilla. No es simple convencer a las personas sobre la importancia sagrada de las cosas, sobre todo con el evidente contrasentido de que no las traen cuando llegan a la vida y no se las llevarán cuando se vayan. Sin embargo, por difícil que parecía, la tarea fue posible ya que contaron con los recursos necesarios: por una parte, con el conocimiento para seducir a las masas (el discurso publicitario), y la tecnología, por otra, para generar los productos mediáticos necesarios. "En el caso chileno la oleada neomordenizadora se acoplará con un consumo masivo de cultura audiovisual a partir de inicios de los ochenta, básicamente con el auge de la televisión en los más variados estratos sociales y económicos de la sociedad" (Cárcamo-Huechante, 26).

Se pone en movimiento, entonces, un sólido discurso mediático que logra incidir en el imaginario de los nuevos tiempos, el que se manifiesta en ideas fuerza, enunciados, imágenes/conceptos/símbolos bastante evidentes y característicos que perfectamente, y haciendo un guiño a Jung, podrían apellidarse de arquetípicos, es decir, imágenes-conceptos arquetípicos del mercado.

Desde el siglo pasado y el inicio del nuevo comienza un interesante proceso discursivo que modifica las formas de la comunicación de masas. Desde el predominio del discurso escrito, básicamente la prensa y luego las revistas ${ }^{17}$, a la irrupción del discurso audiovisual liderado fundamentalmente por la radio y el cine. Podríamos decir que se transitó en menos de un siglo desde el discurso escrito al discurso audiovisual. No desaparece el texto escrito, pero sí, en este contexto, perdió su autonomía y quedó supeditado a la imagen.

Claramente, en esta transformación la industria publicitaria hizo importantes aportes. Fueron los anuncios de este tipo los que contribuyeron de forma decisiva a esta metamorfosis, descubriendo en la prensa y revistas, primero (dibujos y fotografías), luego en y junto al cine, y la televisión después, la potencia significante y de re-significación de la imagen en las grandes audiencias, entendida tanto como representación icónica mental (imágenes mentales) o como representación visual.

Pero cómo estamos entendiendo el concepto "imagen":

17. Si bien comienzan a aparecer dibujos y fotografías (ya a fines del siglo XIX en nuestro país) tanto en periódicos como en revistas, estas lo hacen para ilustrar lo que el texto enuncia, es decir, están todavía al servicio del texto del que forman parte. 
"Una imagen es un sistema de representación a través del lenguaje visual, es decir, es una construcción de carácter ficticio, entendiendo por ficción aquello que no es realidad. Sin adentrarnos en una complicada disertación filosófica para diferenciar entre lo que es la realidad y lo que no lo es [...], solo nos interesa dejar claro que una imagen no es la realidad: las imágenes son hoy más que nunca, tergiversaciones intencionadas de la realidad, construcciones hechas por alguien para algo, en la mayoría de los casos con intenciones muy concretas" (Acaso, 2006, 15).

María Acaso nos ayuda a entrar rápidamente en materia, especialmente cuando afirma: "Esta ausencia de frontera entre realidad y representación nos lleva a afirmar que el poder que tienen las imágenes sobre nuestro concepto de verdad es tal, que todos nosotros consideramos cierto lo que a través de ellas se representa. El efecto realidad (denominado así por Roland Barthes en su libro La cámara lúcida) hace que entendamos cualquier representación visual como un documento y, por tanto, no pongamos duda en su contenido" (11).

Así, queda establecido un primer nudo: las imágenes son ficción, son una representación, no son la realidad. Es la misma autora quien va a establecer la segunda propuesta clave para este texto: "Lo importante de estas imágenes es que generan conocimiento" (15).

Cada día una persona común y corriente se ve enfrentada a una enorme cantidad de imágenes (800 imágenes al menos, afirma Acaso), número que va en aumento según la expansión que hace la publicidad al incorporar nuevos soportes: bandas en los pasamanos de escaleras, grandes pantallas junto a los caminos o en plena ciudad, en las hebillas de los cinturones de seguridad de los aviones comerciales, en las puertas, techos y costados de los medios de trasporte, en las barreras de contención de las canchas de fútbol, en las paredes de basureros, hasta en el cielo con anuncios transportados por aviones. Si consideramos que cada imagen genera conocimiento, sería hora de preguntarnos qué conocimiento (consciente e inconsciente) estamos generando con esa extrema y desregulada exposición.

Creo que el discurso hegemónico que se reconstruye con "el retorno a la democracia" y que se articula tomando prestados los recursos, estrategias y soportes del discurso publicitario, lo tiene muy claro. Es más, está tan al tanto de esta construcción de conocimiento que se realiza con la exposición a cada imagen que ha invertido grandes esfuerzos y dinero para usarlo a su favor.

Me aventuro a proponer un movimiento que opera como una gran metáfora, que en parte explica el Chile de mercado de hoy. Es como si junto con la desaparición (por no decir "asfixia económica") de los medios opositores al régimen dictatorial y con los empeños refundacionales de sus adeptos, se hubiese puesto en funcionamiento 
una gran cámara, la que primero paneó por el tejido social, pero intencionadamente se detuvo, se paralizó y luego realizó un zoom (una aproximación) en un solo sector/ espacio/referente social, el segmento o grupo socioeconómico $A B$, clase alta en la nomenclatura de la clasificación socioeconómica del país ${ }^{18}$.

Esta focalización, que no corresponde exactamente a este sector privilegiado de la población ya que las imágenes que la re-presentan, como vimos, son una construcción, una elaboración, ha invadido durante los últimos 20 años nuestro campo audiovisual, principalmente desde la televisión y los anuncios que repletan los espacios urbanos.

De este modo, el discurso hegemónico del mercado realiza un sólido proceso de consolidación mediante la instalación de un Chile ideal, proyectado en un único estrato socioeconómico ${ }^{19}$, que a fuerza de repetición, tanto en el tiempo como en la utilización de múltiples formatos, intenta convencer o persuadir según el discurso publicitario, y principalmente con las imágenes que difunde, que eso somos, o al menos deberíamos ser los chilenos y chilenas.

Este bombardeo de múltiples imágenes acompañadas de un texto subordinado a ellas genera lo que María Acaso ha definido como:

"las metanarrativas visuales, término que procede del término gran relato, acuñado por Jean Francois Lyotard en su obra La Condición Posmoderna [...] con la intención de transmitir el conjunto de relatos emitidos por el poder, es decir, la información que producen los Estados, las grandes empresas y las religiones, fundamentalmente" (30). En el caso chileno, todas las anteriores.

Esta metanarrativa visual, entonces, que se construye en parte por la televisión y carteles publicitarios de nuestro país, lo hace desde la ficcionalización de una "clase alta ideal" sobre la que se realizan cortes y adecuaciones para que sea funcional al objetivo central del sistema de mercado, mover al consumo (exacerbado). Así, esta élite opera a través de las imágenes que la representan en la televisión y en los anuncios en los espacios urbanos como un modelo, como un patrón arquetípico del mercado al que responder. Algunos ${ }^{20}$ de estos cortes y adecuaciones, que prescriben

18. Corresponde a un análisis estadístico de estratificación social que considera como criterios de diferenciación los ingresos y el nivel de estudios alcanzados.

19. Si bien ocasionalmente se difunden imágenes correspondientes a los estratos medios y bajos, estas apariciones son escasas e instrumentales, ya que se usan exclusivamente para proyectar la idea, falsa por lo demás, de lo inclusivo o, más bien, integrador del modelo.

20. Se describirán los imprescindibles, pero sin duda son muchos más que los que aquí se trabajarán. 
el tipo y configuración de las imágenes a las que nos vemos expuestos, se van a describir a continuación y se sitúan en los siguientes aspectos:

La raza: pese a que concuerdo con el actual cuestionamiento del término para referirse al homo sapiens, lo uso aquí en la idea de destacar ciertos rasgos fenotípicos que establecen variaciones físicas y de color de piel. En esta idea, el metarrelato visual difunde las características físicas ${ }^{21}$ de la "raza blanca", que define una tonalidad de piel clara y que está asociada a poblaciones de origen europeo. Aquí tenemos un primer contrasentido o montaje, aludiendo a párrafos anteriores, especialmente si consideramos que somos un país mestizo, con características físicas heredadas de los pueblos que nos dieron origen.

El género: es indiscutible que el mayor valor y protagonismo ${ }^{22}$ en la representación lo tienen los varones. Son los hombres quienes operan en estos mundos visuales ${ }^{23}$ como los "personajes" más importantes. Se hace evidente, así, un segundo montaje, ya que estadísticamente la población del país está constituida por un poco más del $51 \%$ de mujeres ${ }^{24}$. Además con alta frecuencia las mujeres representadas aparecen cosificadas y en función del deseo e interés que pueden despertar en los hombres. Así, no consiguen constituirse en protagonistas, ya que se presentan como "otro objeto a consumir" o como otredad, sujeto que se completa en la relación con lo verdaderamente protagonista, lo masculino, y las mujeres solo masculinizándose (principalmente en sus acciones) se acercan a esta condición. La imagen siliconada e intervenida quirúrgica y tecnológicamente nada tiene que ver con la inmensa mayoría de nosotras.

La edad: en el mundo de la metanarrativa visual del mercado es clara la predominancia de personas jóvenes, sus edades van de los 15 a los 25 años, más o menos. Si bien aparecen niños o adultos mayores, su presencia es relevante solo en contextos muy definidos. Es más, cuando se trata de anuncios o programas para la tercera edad los actores o entrevistados que los personifican se tienen que ver más jóvenes de lo que realmente son, personas sobre los 80 años son realmente

21. Estas características dan origen a un patrón de belleza que opera como un modelo a seguir y al ser prácticamente inalcanzable con nuestros antecedentes genéticos, abre para el mercado un increíble espectro de productos y servicios para vender.

22. Es impactante ver, por ejemplo, en los programas de debate o reflexión en TV la casi nula participación de mujeres, situación que se extrema en lo que respecta al fútbol, el que ocupa importantes espacios televisivos, ya sea a través de la transmisión de partidos o de sus comentarios y análisis posteriores.

23. María Acaso define los mundos visuales como "mundos paralelos al mundo real, construidos a través del lenguaje visual, que tienen una influencia en nuestra identidad y nuestros quehaceres cotidianos cada vez mayor que la propia realidad".

24. Censo 2017. 
exóticas. En otras ocasiones en que se difunden imágenes de personas mayores estas son estereotipadas y se operacionalizan en contrapartida a los jóvenes que ya no son, nos enfrentamos así a "la vieja loca" o al "viejo verde". Esta focalización en una sola etapa de la vida (además, bastante breve) produce un efecto de eternidad, es decir, se niegan las etapas transicionales de la existencia, generando un terror al envejecimiento ${ }^{25}$ y una negación sistemática de la muerte. La consecuencia, entonces, es producir una permanente incomodidad y rechazo a los cambios naturales asociados al paso de los años, lo que obliga a consumir juventud haciendo ganar a la industria cosmética, médica, farmacéutica y del retail enormes ganancias.

El objeto del deseo: en este escenario representacional, así como hay un reducido tipo de personajes, hay también un número limitado de acciones que los movilizan. Estos maqueteados referentes persiguen, casi patológicamente, solo cierto tipo de placeres. Pasear, beber (cerveza, especialmente), comer (básicamente, comida chatarra), ver fútbol, acicalarse, seducir y recrearse a base de recursos tecnológicos son los quehaceres que estos nuevos héroes realizan y con los cuales detonan el consumo. Pero todas estas acciones se concretan, generalmente, desde la individualidad; lo colectivo o comunitario se ve reducido a la familia (mononuclear) o a un mínimo grupo de amistades. Se desarticula así, de modo sistemático y permanente, la visión comunitaria, la que incluso se sataniza a través del recuerdo siempre sesgado y estereotipado de periodos históricos en que esta visión de sociedad fue estructural y de gran relevancia; me refiero al periodo de la Unidad Popular ${ }^{26}$, por ejemplo, donde la concepción de pueblo o de "lo popular" contenía la idea de un cuerpo social organizado y movilizado en la búsqueda de mejores condiciones no solo económicas sino también sociales y culturales.

A partir de estas focalizaciones y adecuaciones se establece un mundo representacional, un imaginario que sitúa a las personas en un contexto en el que solo hay un deseo que los contiene a todos: el consumo.

25. Me atrevo a decir que la metanarrativa visual del mercado nos robó el derecho a la vejez: está "prohibido" envejecer, cada cambio corporal que da cuenta de ello está asociado a lo feo, es trágico y completamente indeseable... sin embargo, en cada minuto es eso lo que hacemos, otro peligroso contrasentido/montaje.

26. Es interesante observar el proceso de satanización y estereotipación de este periodo histórico, el que a partir de un férreo y constante proceso de reducción ha logrado ser instalado en el imaginario colectivo como una época oscura y violenta. Recién en los últimos años se ha iniciado una etapa en la que se intenta completar la mirada a través de la valoración de las iniciativas del gobierno de Salvador Allende en el ámbito de la salud, de la producción y especialmente del arte, la educación y la cultura, muchas de ellas sin precedente en la historia del país. 
"El consumo deviene en esclavitud cuando el afán compulsivo de consumir se convierte no en un deseo sino en el deseo, sustituto del Eros. Ahí estaríamos en presencia de una objetofilia, de una idolatría. De un tipo de práctica que aleja al individuo del centro de la existencia. O sea estaríamos hablando de una situación dónde el privilegio otorgado a los objetos o placeres del consumo interfiere en las relaciones con los otros" (Moulian, 65).

Como país (sin dejar de reconocer que muchos de estos dispositivos son hoy globales) hemos sido prefigurados por el discurso hegemónico del mercado, su metanarrativa visual, que opera como una matriz de sentidos que se auto regenera y establece lo que es "visible", principalmente a través de la televisión y las imágenes a las que nos exponemos en los espacios públicos. O, dicho de otro modo, se configura un universo representacional que ilumina ciertos aspectos y oculta otros. Son esos espacios de "sombra", de negación, de ocultamiento, los que creo que también nos dan las claves para su desarticulación o, al menos, las herramientas para su cuestionamiento y lectura crítica, lo que puede permitirnos, en un segundo momento, dimensionar la magnitud del daño.

El sistema cultural de mercado, según la teórica feminista chilena Margarita Pisano, no es más que la consolidación y apogeo de la cultura patriarcal, entendiéndola como un sistema civilizatorio-cultural basado en relaciones de dominio. Margarita escribe: "La cultura patriarcal se sostiene en el deseo de lo otro. 'Yo quiero lo que tú tienes', 'yo quiero lo que tú eres', 'yo quiero todo lo que existe', 'yo quiero para mí todo': hombre, mujer, niño, niña; la tierra, el agua, el aire. 'Quiero la guerra, si no, ¿cómo soy un héroe y justifico los galardones en un traje guerrero desbordante de oro, que me significa?'. 'Quiero la vida privada, pero también necesito la privadaprivada, la más guardada y que esté farandulizada'27" (Pisano, En pleno disfraz, desde las profundidades del patriarcado).

Así, la cultura visual del sistema de mercado presente en la TV y el espacio público establece una mitología que levanta a este "nuevo guerrero", blanco,

27. Margarita instala con este último vocablo un elemento de gran relevancia para este análisis, que se refiere a la farándula y su cercanía con el concepto de espectáculo. La cultura de masas del mercado se configura en base a la espectacularización, es decir, a transformarlo todo en un espectáculo. Renta a partir de "subir al escenario" o al set de grabación todo lo que no corresponde o no debiera estar alli: el mundo privado. Así lo convierte en la gran entretención pública, la cámara opera como el ojo tecnológico del voyeur que intenta satisfacer su deseo mirando, lo que en este contexto opera como una posibilidad de realización, de ser y estar en la existencia. 
heterosexual, con dinero para gastar ${ }^{28}$ (las mujeres ni siquiera alcanzan el estatus de compañeras, ya que su cosificación las transforma también en objetos de consumo), bello (en la medida que responde a cánones de belleza europea o los simula), joven, viril (natural o farmacéuticamente) y altamente hedonista. Esto se completa con "su apero", está dotado de potente cabalgadura (la industria automotriz) y eficientes armas (la tecnología), así impone, a través de su imagen y acciones, un estilo de vida, un modo de estar en la tierra y de relacionarse con ella (depredación y extractivismo), y con los otros y otras (individualismo y competencia). En contrapartida, surge "la dama del guerrero" para ser admirada, deseada, complacida, satisfecha, pero no es, es lo que puede llegar a ser, por eso debe comprar. Su ajuar está compuesto por innumerables recursos de vestuario y cosméticos, y sus labores y trabajos se orientan a ser para otros.

Estas concepciones o imágenes arquetípicas del mercado impregnan y condicionan el discurso que la televisión y los anuncios callejeros producen y masifican. Su aparición puede ser explícita y denotativa, pero es mayoritariamente implícita y connotativa, más bien se aluden, se invocan, se construyen en una multiplicidad de voces, imágenes y emisores tanto en los programas televisivos como en los espacios para la publicidad en este medio y en el espacio urbano.

\section{LAS AUSENCIAS QUE ESAS IMÁGENES/PRESENCIAS EVOCAN}

Interroguemos, entonces, a lo que queda en las sombras, a las ausencias, a los ocultamientos que este discurso hegemónico en la televisión y en la iconografía de los anuncios publicitarios del espacio callejero crea y produce. Comencemos el proceso con su conducta-símbolo: el consumo. La investigadora norteamericana Annie Leonard plantea que las cosas que compramos y que después desechamos pasan por distintas fases: extracción, producción, distribución, consumo y descarte, lo que llama economía de materiales. No obstante, este sistema está en crisis porque

28. Entonces, el dominio toma forma en la "capacidad de pago", pago y puedo comprarlo todo o "todos tienen un precio". Se establecen relaciones de subordinación en base a los recursos económicos que se manejan. Pago y mando. Me pagan y debo obedecer, lo que se resume magistralmente en la máxima del mercado "el cliente siempre tiene la razón" (porque está pagando). Se genera así una "nueva" escala de valores que legitima las decisiones de los dueños del capital, sacraliza sus acciones pese a que su codicia nos tenga al borde del colapso ambiental y social. Esto hace que la "democracia" a la que transitamos sea más un simulacro que un modo de organización real. Cada cuatro años hacemos una marca en el voto mientras todos los días se toman decisiones, muchas veces "entre privados", que nos afectan directamente, estableciendo múltiples zonas de sacrificio. 
se trata de un sistema lineal y porque vivimos en un planeta finito, limitado. Esta crisis, según la autora, se genera porque "el 99\% de las cosas que recogemos, extraemos, fabricamos, transportamos, serán desechos en menos de 6 meses" (44). Vemos aquí el primer mecanismo de macro-ocultamiento, ya que según Leonard, lo único que el discurso mediático muestra e intensifica es la fase del consumo y oculta y niega todas las demás: de extracción, producción, distribución y especialmente la de descarte o deshecho. Esto se hace muy evidente en los anuncios publicitarios presentes en los espacios públicos, solo vemos los bienes y servicios en oferta, se clausuran en sí mismos, lo que hace a fuerza de repetición que se pierdan de vista sus consecuencias de producción y descarte para el planeta y las personas. Son imágenes focalizadas en la penúltima etapa del proceso, el producto para ser adquirido ocultando con su incesante repetición las etapas previas y posteriores, y aniquilando la posibilidad de tomar consciencia del proceso completo.

Veamos ahora una segunda estrategia de macro-ocultamiento. La incitación al consumo a través de la producción de imágenes claramente pone el énfasis en los beneficios y placeres a los que accedemos con la adquisición de tal o cual bien o servicio, y es la televisión abierta uno de los espacios estratégicos para ello ${ }^{29}$. Al igual que en el espacio físico de la tienda o supermercado, el objeto o bien a consumir aparece rodeado de neón, colores, grata música, seductores aromas y alguna bella promotora que completa el cuadro. Todo parece accesible y perfecto, incluso cuando llega el momento de cancelar, ya que el mismo sistema de mercado ofrece una amplia gama de "posibilidades" para ello. Cómo olvidar los miles de anuncios ofreciendo tarjetas de crédito, préstamos bancarios y dinero plástico en los horarios prime, minutos antes de que se inicien los noticieros televisivos. Pero los colores, el neón y la señorita sonriente y atenta desaparecen, como un sueño que se esfuma, apenas hemos cerrado la compra. Entonces, a la hora de pagar "en cómodas cuotas mensuales" el espacio ya no es el escenario multicolor de la tienda sino una oficina pequeña, sin su glamour y trato preferencial. Habitualmente se trata de espacios reducidos en los que muy pocas personas deben atender a una gran cantidad de pagadores, muchos de ellos morosos, para los que se acabaron las sonrisas y las atenciones. Este otro ocultamiento es la antesala de uno con

29. En los últimos años hemos sido testigos de una importante reducción en la duración de los espacios televisivos destinados a los programas y, en contrapartida, a un aumento cada vez mayor del tiempo de los anuncios publicitarios. Lo que lleva a Jesús González Requena a afirmar: "La televisión es el discurso de la publicidad interrumpido por programas" (Citado por Gabriela Fabbro). Además, hay que considerar que los mismos programas televisivos incorporan cada vez con mayor frecuencia estrategias que les permiten hacer publicidad dentro de sus propios formatos de forma sutil y encubierta. 
consecuencias más fatales aún: el endeudamiento. Llama la atención la legalidad de este proceso en la televisión de nuestro país, que condena a los consumidores ingenuos o sin las herramientas necesarias para una observación crítica (fruto de nuestra educación de mercado) a situaciones de extrema gravedad que concluyen, muchas veces, en el embargo y pérdida de la infraestructura básica, en profundos estados de depresión y en la pérdida de la paz y la seguridad personal y familiar. Los horarios de mayor audiencia en televisión abierta están plagados de anuncios que desde una sospechosa regulación ofrecen sistemas de endeudamiento, los que se transforman a poco andar en una efectiva y eficiente forma de control social. A la sazón, para responder es necesario tener más de un trabajo y realizar extensas jornadas laborales que limitan peligrosamente el tiempo para descansar y reponerse, para compartir con los seres queridos, para efectuar actividades de realización personal y participar con otros y otras en la concreción de proyectos colectivos y/o comunitarios. Excelente estrategia para instalar el individualismo y la competencia, engranajes fundamentales del sistema de mercado. Para qué vender un refresco en envase familiar cuando puedo vender el doble, el triple o el quíntuple de envases individuales.

\section{LAS ZONAS DE TENSIÓN EN EL DISCURSO OPOSITOR A LA DICTADURA Y SU CONTINUIDAD COMO AUSENCIAS DETONANTES EN EL DISCURSO HEGEMÓNICO DEL MERCADO}

Al momento de intentar una caracterización del discurso opositor al régimen militar, como confrontación a su discurso hegemónico se identificaron zonas de tensión, específicamente referidas a ciertas temáticas que se evitaron o que fueron visibles de forma eventual y acotada en esa producción discursiva, mayoritariamente masculina. Las mujeres como emisoras tuvieron muy baja participación en ambos "bandos". Estas zonas de tensión se estructuraron en base a demandas específicas de las mujeres (desde un enfoque feminista), la diversidad sexual y los pueblos originarios.

Para el Chile de la transición, tanto de izquierda como de derecha, estas temáticas resultaban "incómodas", por lo que se evitaron, suspendieron, ignoraron, lo que se tradujo derechamente en una ausencia forzada, en una invisibilidad estimulada especialmente por la necesidad de llegar a consensos.

En el discurso hegemónico del mercado de la actualidad es interesante ver cómo estas zonas de tensión continúan operando en la televisión abierta y en las imágenes en espacios públicos, pero con variaciones importantes, entre las que se destaca la estereotipación (construcción de estereotipos) y/o la bajísima frecuencia de aparición. 
No sería cierto decir que el discurso hegemónico de mercado no considera a las mujeres, primera zona de tensión; muy por el contrario, ellas tienen una gran frecuencia de exposición en los distintos espacios televisivos y en las imágenes que forman parte de los anuncios en calles y autopistas. El problema radica en el tipo de mujeres que se presenta o, mejor dicho, que se construye a partir de esa exposición. Bien sabida y estudiada, principalmente por el feminismo, es la apariencia física de estas mujeres, en general rubias, delgadas, pero curvilíneas y jóvenes, lo que establece un canon de belleza muy distinto al que nos corresponde como pueblo mestizo y niega las profundas modificaciones que el paso de los años trae consigo. Esto hace que tengamos instalado en nuestro imaginario un patrón de belleza (y que mueve compulsivamente al consumo) que nos es imposible encarnar, produciéndonos serias dificultades en nuestra auto percepción, imagen de sí mismas y seguridad personal.

Pero quiero avanzar en otro sentido menos explorado y más peligroso aún, y que radica en el rol que se nos asigna en esa exposición mediática. Las mujeres representadas son novias o esposas, o pueden y tienen que llegar a serlo; son madres o tienen que llegar a serlo; son sumisas o tienen que serlo. En estas afirmaciones se oculta lo que ya anticipábamos, un claro ser/estar para otros. El cuestionamiento de uno o todos estos supuestos pone en riesgo la estructura central del sistema de mercado, que es el apogeo del sistema patriarcal, recordando a Pisano, y que centra su accionar en la constitución de la familia nuclear (en la que no caben los abuelos, las tías/os solteronas/es o quienes no logran generar sus propios ingresos). Cuestionar la estructura significa deslegitimar y poner en riesgo el sistema económico. Si no son las mujeres las que tienen la responsabilidad del trabajo doméstico y la reproducción (los hombres "ayudan"), quién debería pagar lo que significa la gestación, la crianza, formación y "mantención doméstica" de una persona. No es casual que este gasto, costo o inversión no se considere en los ámbitos y cifras que mueven la economía nacional y global. Lo mismo sucede con el cuidado de las personas mayores o con problemas en su auto valencia, que misteriosamente también deben asumir las mujeres. La sumisión y “entrega a los demás” que este rol conlleva es fundamental para mantener el equilibrio.

Algo similar sucede con una segunda zona de tensión, la referida a la diversidad sexual, que también desestabiliza el núcleo "sagrado" de la familia ${ }^{30}$ al poner en evidencia otras formas de vivir la sexualidad en los extramuros de ella y lejos de sus fines reproductivos. Si bien hay gestos de su inclusión, en el discurso mediático de la TV abierta sigue estando presente estereotipadamente como un "ineludible" en

30. La familia de mercado, entendida como el grupo básico de la sociedad de mercado y conformada por un hombre (padre) y una mujer (madre), cuyo fin es la procreación. 
el discurso hegemónico del mercado. Pero claramente es un elemento de desorden, que altera y cuestiona el ordenamiento genérico de lo "masculino" y "femenino", géneros que prescriben la oferta, hacen posible el diseño y la producción de miles de objetos y servicios especialmente pensados para hombres y otros para mujeres: el rosadito con flores para las niñas y el celestito con autitos para los niños. Así se abren mercados diferentes y diferenciados, lo que duplica la demanda.

Finalmente, la última zona de tensión da cuenta del permanente e histórico silenciamiento en nuestro país de la imagen y presencia de los pueblos originarios, a los que tampoco, como las y los anteriores, vemos en imágenes en la televisión abierta y en los anuncios callejeros, y si los vemos es de forma estereotipada, especialmente en noticieros y recuentos informativos en los que aparecen relacionados a la "violencia rural" o reducidos al marco del mal llamado "conflicto mapuche". En Chile, a diferencia de otros países en Latinoamérica, no les observamos en la calle ataviados con sus vestimentas y atuendos típicos: eso no es casual, es síntoma de la incompatibilidad cultural que tienen con la cultura impuesta por el mercado. Hablamos de pueblos originarios, pero especialmente del pueblo mapuche, que ha resistido a esta imposición por múltiples razones, pero básicamente por la enorme diferencia en la cosmovisión del entorno natural y las estrategias para su explotación. Para esta etnia, gente de la tierra, la tierra no es de la gente, los seres humanos pertenecen al planeta y no al revés como plantea el libre mercado. Desde esta perspectiva, lo que para la economía de mercado es producción forestal a gran escala, para los mapuche es extractivismo y depredación de la madre tierra. Lo que para los hijos del mercado es sana competencia y triunfo de la iniciativa personal, para la gente de la tierra es la amenaza a los valores colectivos y comunitarios en los que se centra su cultura. Por eso su imagen, su representación, no es pertinente en la iconografía de la televisión y de los espacios públicos, no calza.

En base a este planteamiento es posible afirmar que estas ausencias de antaño siguen siendo las no presencias de hoy, pero con estrategias diferentes. Mecanismos que dejan al descubierto ciertas concepciones/esencias que van más allá del modelo económico y cultural del mercado, que lo trascienden, aspectos que corresponden a una forma de construir sociedad, de hacer civilización.

\section{A MODO DE SÍNTESIS}

Al finalizar esta larga reflexión que desde el pantanoso terreno de la subjetividad se focaliza en la recepción crítica de las imágenes y ejemplifica con la televisión abierta y los anuncios en espacios públicos, es posible proponer que ellas son centrales y 
fundacionales en el imaginario de la cultura de mercado. Esta iconografía ilustra y da forma a un nuevo discurso hegemónico en el país: el del mercado.

Discurso que se hace hegemónico a través de tres estrategias o maniobras: (I) la concentración de medios masivos en la que la televisión es uno de sus mejores ejemplos; (II) la expansión a otros ámbitos de enunciación de los recursos de la producción discursiva publicitaria en la forma y los principios del discurso económico en el fondo; y (III) la formación de las audiencias capaces de recepcionar y adherir a este discurso: la educación de mercado.

En este contexto, el principio transversal y articulador del mercado, el consumo, pone en operación ciertas focalizaciones, cortes o adecuaciones, reduciendo el espectro de lo que vemos, de las imágenes a las que estamos expuestos tanto en la TV abierta como en la iconografía expuesta en los espacios públicos como calles y autopistas. Reducciones que se focalizan en: un determinado grupo socioeconómico (la clase alta); un género protagonista, el masculino (lo femenino se cosifica); una determinada edad (la juventud) y un número limitado de acciones: pasear, beber, comer, ver fútbol, acicalarse, seducir y recrearse a base de recursos tecnológicos.

Sin embargo, la repetición de estas reducciones no funciona eternamente y menos cuando las consecuencias del modelo de mercado quedan a la vista (cambio climático, múltiples zonas de sacrificio e importantes migraciones). El descontento y rechazo que produce se manifiesta en la irrupción de fuertes estallidos sociales y masivas acciones de protesta que sobrepasan la acción de la política tradicional y cuestionan las formas actuales de organización, producción y reproducción, donde las mujeres, la diversidad sexual y los pueblos originarios, entre otros, aparecen tensionando y develando con la irrupción de su presencia los ocultamientos del modelo.

Pero este nuevo discurso hegemónico, que hemos ejemplificado en este texto a través de las representaciones visuales que construye, comienza a ser impactado por nuevas formas y canales de comunicación. La web y las redes sociales hacen emerger a otras y otros emisores, lo que se evidencia en la emergencia de nuevas imágenes, de otros enunciados que abren el espectro y permiten pensar en nuevas formas de ser y estar en la vida y en la tierra. Es decir, cuestionan la sociedad de mercado y hacen posible imaginar otras formas de organización, producción, reproducción y generación de cultura, y que invitan a un cambio civilizatorio-cultural, como nos interpelaba Margarita Pisano, que deje atrás el consumo exacerbado, el dominio de unos sobre otras, sobre otros, sobre el planeta, y nos permita comenzar a pensar en otras maneras de hacer cultura, de hacer civilización, considerar a “... las personas como individuas completas en sí mismas, con capacidad de inventar sus propias formas de relacionarse, de reproducirse, de amarse y respetarse, primero a sí mismas y luego a todo lo que las rodea y sostiene" (Pisano, 2015, 18). 
En la televisión abierta y en la iconografía presente en los espacios públicos el discurso hegemónico del mercado sigue modelando y estableciendo la conformación y características de las imágenes que vemos, representaciones que configuran el imaginario de la cultura de mercado. Mientras eso no cambie, Ana González tenía toda la razón, no le ganamos a Pinochet porque seguimos viviendo en el Chile que él soñó.

Desde esta mirada, no fue una transición a la democracia, fue una transición hacia el neomercado. 


\section{REFERENCIAS}

ACASO, María: La educación artística no son manualidades. Nuevas prácticas en la enseñanza de las artes visuales y la cultura visual. $2^{\mathrm{a}}$ ed. Madrid. Los libros de la Catarata. 2010.

ACASO, María: Esto no son las Torres Gemelas. Cómo aprender a leer la televisión y otras imágenes. Madrid. Los libros de la Catarata. 2006.

ACASO, María: El lenguaje visual. Barcelona. Editorial Paidós. 2009.

ÁGUILA, Ernesto: Educación de mercado [En línea] La Tercera. http://diario. latercera.com/edicionimpresa/la-educacion-de-mercado/ [consulta: 20 de noviembre 2018].

ÁLVAREZ, Gerardo: Textos y discursos. Introducción a la lingüistica del texto. $3^{\mathrm{a}}$ ed. Concepción. Editorial Universidad de Concepción. 2014.

BARCIA, Pedro: No seamos ingenuos. Manual para la lectura inteligente de los medios. Buenos Aires. Ediciones Santillana. 2008.

BARTHES, Roland: La cámara lúcida: nota sobre la fotografía. Barcelona: Paidós, 1998.

Breull, Luis Adolfo: Consejo Nacional de Televisión, CNTV. Estudio sobre la concentración de la propiedad de los medios de comunicación en Chile. 2015.

CÁRCAMO-HUECHANTE, Luis: Tramas del mercado: cultura pública y literatura en el Chile de fines de siglo veinte. Santiago de Chile. Editorial Cuarto Propio. 2007.

CORRALES, Osvaldo y Sandoval, Juan: Concentración del mercado de los medios, pluralismo y libertad de expresión [En línea]. Centro de Estudios de la Comunicación, Instituto de la Comunicación e Imagen, Universidad de Chile.

www.uchile.cl/.../descargar-texto-completo-del-articulo-pdf-196kb_25646_0.pdf [consulta: 02 noviembre 2018]

CORVALÁN, Javier y García-Huidobro, Eduardo: La educación de mercado en Chile y su propuesta de superación. Universidad Alberto Hurtado, Facultad de Educación, Cuadernos de Educación Nº6, junio 2015.

FABBRO, Gabriela: El lenguaje audiovisual. En BARCIA, Pedro (Coordinador), No seamos ingenuos. Manual para la lectura inteligente de los medios, Argentina, Ediciones Santillana S. A. 2008.

FIGUEROA, Natalia: Concentración de medios amenaza la democracia y la libertad de expresión [En línea]. Diario UChile 5 de octubre 2016 https://radio.uchile. $\mathrm{cl} / 2016 / 10 / 05 /$ alta-concentracion-de-medios-amenaza-la-democracia-ylibertad-de-expresion [consulta: 28 de octubre 2018]. 
GRAU, Olga, DELSING, Riet, BRITO, Eugenia, FARÍAS, Alejandra: Discurso, género y poder, discursos públicos: Chile 1978-1993. Santiago, Serie Punto de Fuga, COLECCIÓN SIN NORTE, La Morada, ARCIS, LOM, 1997.

GUZMÁN, Jaime: Reagan y el fracaso socialista, Revista Ercilla, noviembre de 1980.

MONTES, R.: La eterna búsqueda de Ana González, La Pasionaria chilena [en línea]. El País en Internet, 11 de septiembre, 2018. https://elpais.com/ internacional/2018/09/10/america/1536601171_086636.html [consulta: 20 noviembre 2018].

ELLSWORTH, Elizabeth: Posiciones en la enseñanza. Diferencia, pedagogía y el poder de la direccionalidad. Madrid. AKAL Ediciones. 2005.

Klein, Noemí. La doctrina del shock. El auge de capitalismo del desastre. Argentina: Editorial Paidós. 2008.

LEONARD, Annie: La historia de las cosas. Buenos Aires: Fondo de Cultura Económica, 2010.

LYOTARD, J. F.: La condición posmoderna. Madrid: Cátedra. 1984.

MEDINA-SANCHO, Gloria: A partir del trauma: narración y memoria en Traba, Peri Rossi y Eltit. Santiago de Chile. Editorial Cuarto Propio. 2012.

MORRESI, Zulema. "El discurso publicitario. Su especificidad y desarrollo" en La Trama de la Comunicación, Volumen 11. Editorial UNR. Rosario. 2006.

MOULIAN, Tomás: El consumo me consume. $5^{\text {a }}$ ed. Santiago de Chile. LOM Ediciones. 1999.

PISANO, Margarita: El triunfo de la masculinidad. Santiago de Chile. Surada Ediciones. 2001.

PISANO, Margarita: Fantasear un futuro: introducción a un cambio civilizatorio. Santiago de Chile. Editorial Revolucionarias. 2015.

PISANO, Margarita: En pleno disfraz, desde las profundidades del patriarcado [En línea]. http:/ / www.mpisano.cl/en-pleno-disfraz-desde-las-profundidades-delpatriarcado/ [consulta: 5 de noviembre 2018].

Retamal, Jaime: Nos siguen pegando abajo. Jaime Guzmán, dictadura, Concertación y Alianza: 40 años de educación de mercado. Santiago de Chile. Ceibo Ediciones. 2013.

ROZAS, G. y ARREDONDO, J: Identidad, comunidad y desarrollo. Magister Psicología Comunitaria y MIDEPLAN, 2006. Santiago de Chile. Universidad de Chile, Facultad de Ciencias Sociales, Departamento de Psicología, Magíster Psicología Comunitaria. 2006. 
SÁNCHEZ-GUZMÁN: Breve historia de la publicidad, Ediciones Pirámide, Madrid, $\mathrm{S} / \mathrm{F}$.

RUIZ, Carlos: Construcción de identidad, creación de sentido. Santiago de Chile. Editorial Universitaria. 2014.

RUIZ, Carlos: Educación, mercado y privatización [En línea]. http://web.uchile.cl/ facultades/filosofia/Editorial/documenta/reflexunive/08.htm / [consulta: 5 de noviembre 2018].

RUIZ-Tagle, Pablo: Propiedad de los medios y principios de la intervención de Estado para garantizar la libertad de expresión en Chile. Revista de Derecho. Universidad Católica del Norte. Sección Ensayos (año 18-N²) pp. 347-359. 2011. 